\title{
Response of Maize (Zea mays L.) to a Temperature Gradient Representing Long-Term Climate Change Under Different Soil Management Systems
}

\author{
M.A.P.W.K. Malaviarachchi", W.A.J.M. De Costa $^{1}$, R.M. Fonseka ${ }^{1}$, J.B.D.A.P. Kumara ${ }^{2}$, \\ K.M.R.D. Abhayapala and L.D.B. Suriyagoda ${ }^{1}$
}

\author{
Postgraduate Institute of Agriculture \\ University of Peradenya \\ Peradeniya
}

\begin{abstract}
Maize ( $\underline{\text { Zea }} \underline{\text { mays }}$ L.) yields in Sri Lanka have been below its potential yield mainly due to biotic and abiotic stresses. This situation is likely to be aggravated in a changing climate in the future. This study was conducted under field conditions to determine the response of maize to temperature and different soil management practices during Maha season 2012/2013 at five locations (Rahangala, Peradeniya, Kundasale, Mahailluppallama and Kilinochchi) in Sri Lanka representing an environmental gradient together with three soil management systems (SMS) in a Randomized Complete Block Design (T1 - standard management; T2 - standard management plus mulching; T3 - mulching $+75 \%$ of $N$ supplied by inorganic fertilizer $+25 \% N$ from organic manure). The rate of progress to maturity showed a significant positive linear relationship with the mean location temperature (MLT), thus shortening the crop duration with increasing temperature. Leaf area index (LAI) and total dry weight (TDW) at 50\% flowering in all SMSs showed significant second-order polynomial relationships with MLT. The optimum temperatures for the maximum LAI and $T D W$ were 23.0 and $22.8{ }^{\circ} \mathrm{C}$, respectively. Total dry weight of T3 and T2 were $22 \%$ and $9 \%$ greater than $T 1$ thus, showing the beneficial effects of mulching and adding organic manure. The grain yield of maize also showed a significant second-order polynomial relationship with MLT with an optimum temperature of $22.5{ }^{\circ} \mathrm{C}$. It is notable that all major maize growing regions of Sri Lanka (i.e. dry and intermediate zones) have temperatures, which are above the respective optima for growth and yield of maize. Furthermore, the fitted polynomial relationships showed that the rates of decline in maize yield (i.e. $489 \mathrm{~kg} \mathrm{ha}^{-1 /} \mathrm{C}^{-1}$ ), LAI $\left(0.98{ }^{\circ} \mathrm{C}^{-1}\right)$ and TDW $\left(1390 \mathrm{~kg} \mathrm{ha} a^{-1} \mathrm{C}^{-1}\right)$ with each $1{ }^{\circ} \mathrm{C}$ increase in the supra-optimal range of temperatures were greater than the corresponding rates of increase in the suboptimal range $\left(15 \mathrm{~kg} \mathrm{ha}{ }^{-1}{ }^{o} \mathrm{C}^{-1}, 0.33{ }^{\circ} \mathrm{C}^{-1}\right.$ and $330 \mathrm{~kg} \mathrm{ha}{ }^{-1}{ }^{o} \mathrm{C}^{-1}$ for yield, TDW and LAI, respectively). Therefore, increased temperature due to future climate change will have significant negative impacts on maize yields in Sri Lanka, unless more heat-tolerant varieties are bred and introduced.
\end{abstract}

Keywords: Climate change, Temperature gradient, maize, optimum temperature, soil fertility

\footnotetext{
Department of Crop Science, Faculty of Agriculture, University of Peradeniya, Sri Lanka

Faculty of Agriculture, Sabaragamuwa University, Belihuloya, Sri Lanka

Corresponding author:wmalavi@yahoo.com
} 


\section{INTRODUCTION}

Maize, which is consumed either as grains or green cobs, is the second most important cereal crop in Sri Lanka (Anon, 2012). It is widely used in both food and feed industries. Among the major annual upland crops grown by small-scale farmers, maize has received increased attention in recent years due to increased local demand with the expansion of animal feed industry. It is grown in the Dry and Intermediate zones mainly as a rainfed cultivation during the Maha season. This is a cropping system of lower productivity in comparison to irrigated or protected agriculture owing to erratic weather, biotic stresses and poor adoption of improved agronomic practices. Thus, even though maize has a high potential yield (Anon, 1998), the farmers have failed to achieve this potential yield at field conditions (Anon, 2012). This situation may be aggravated in a changing climate in the future. Being a $\mathrm{C} 4 \mathrm{crop}$, maize is more adapted to higher growing temperatures. However, even $\mathrm{C} 4$ crops would be adversely affected when the temperature exceeds critical thresholds. Therefore, it is important to evaluate the response of maize to increasing temperature over a wide temperature range.

Climate change in the $21^{\text {st }}$ century might impact many aspects of the human activities but the well-being of humans will arguably be most influenced by the effects of climate change on agriculture (Cline, 1992). Increasing air temperatures and decreasing rainfall are the major aspects of climate change (Rahmsdorf et al., 2007; Pielke, 2008; Rosenzweig et al., 2008) that influence agricultural productivity.

Reported evidences on climate variation over time in Sri Lanka dates back to the beginning of the $20^{\text {th }}$ century. Seasonal rainfall pattern and its variations have been studied by several scientists using the data available from meteorological stations in different agro - climatic zones of the country (Cook, 1931; Farmer, 1956; Madduma Bandara, 1971; Fernando \& Chandrapala, 1995; Rekha, 2003; De Costa, 2009). Changes in surface air temperature have been studied by Fernando \& Chandrapala (1995), Miyashita (1997), Rekha (2003), Panaboke \& Punyawardane, (2009). All above studies have observed an increasing variability in the rainfall pattern and a gradual warming trend over the country.

In addition to the changing climate, a gradual decline in soil fertility is another major issue which is affecting productivity in upland cropping systems (Nijamudeen et al., 2004). This may have led to increased reliance on inorganic fertilizers by the farmers. Consequently, the cost of production, land degradation and ground-water pollution would increase. Thus, practices aimed at increasing the organic matter content of the soil are recommended to arrest the decline in soil fertility and ensure long-term sustainability of this cropping system. Mulching is one such practice as it adds organic matter while contributing to soil moisture conservation and improved water holding capacity (Kendaragama, 1999).

Very few in-depth research has been done on the impacts of climate change on upland annual crops in Sri Lanka. Furthermore, most work on climate change impacts on crops have been done under controlled environmental conditions. Therefore, this study was conducted under natural field conditions to determine,

i. the response to temperature variation of growth, phenology and yield of maize using the local inbred variety, Ruwan, across a wide temperature gradient represented by a multi-locational study

ii. the response of maize to different soil management practices aimed at improving physical soil fertility while decreasing inorganic fertilizer input 
iii. the effectiveness of soil management practices across the wide temperature gradient.

\section{MATERIALS AND METHODS}

A multi-locational field experiment was conducted during Maha 2012/13 at five locations under supplementary irrigation. The five locations represented an environmental gradient to simulate the effects of long term climate change. The key environmental characteristics of experimental sites are given in Table 1.

Table 1. Key environmental characteristics of experimental sites

\begin{tabular}{|c|c|c|c|c|c|}
\hline Location & $\begin{array}{l}\text { Agro- } \\
\text { ecological } \\
\text { region }{ }^{1}\end{array}$ & Soil type $^{2}$ & $\begin{array}{l}\text { Altitu } \\
\text { de (m) }\end{array}$ & $\begin{array}{c}\text { Mean } \\
\text { annual } \\
\text { rainfall }^{1} \\
(\mathbf{m m})\end{array}$ & $\begin{array}{c}\text { Mean } \\
\text { annual } \\
\text { temperature } \\
{ }^{3}\left({ }^{\circ} \mathrm{C}\right)\end{array}$ \\
\hline Rahangala & $\mathrm{IU}_{3 \mathrm{~d}}$ & Red Yellow Podzolic & 1558 & 1450 & 19.61 \\
\hline Peradeniya & $\mathrm{WM}_{2 \mathrm{~b}}$ & Red Yellow Podzolic & 496 & 2000 & 25.43 \\
\hline Kundasale & $\mathrm{IM}_{3 \mathrm{a}}$ & $\begin{array}{l}\text { Immature Brown } \\
\text { Loam }\end{array}$ & 367 & 1500 & 25.20 \\
\hline $\begin{array}{l}\text { Mahailluppa } \\
\text { llama }\end{array}$ & $\mathrm{DL}_{1 b}$ & Reddish Brown Earth & 117 & 1000 & 27.61 \\
\hline Killinochchi & $\mathrm{DL}_{3}$ & Red yellow Latosol & 15 & 950 & 27.71 \\
\hline
\end{tabular}

Source: ${ }^{1}$ Punyawardana, 2008; ${ }^{2}$ Senarath and Dissanayake.(1999); ${ }^{2}$ De silva et al (2005); De Silva and Dassanayaka (2010); Dassanayake and De Silva (2005); ${ }^{3}$ Natural Resource Management Centre, Department of Agriculture, Sri Lanka. Mean annual temperature was calculated using 10 year monthly average maximum and minimum temperatures (Mahailluppallama, Peradeniya, and Kundasale from 2000 to 2009; Rahangala from 1992 to 2001; Data from Paranthan were used for Killinochchi from 1976-1985).

At each location, three soil management systems (SMSs) were tested using the local inbred maize variety, Ruwan in a nested treatment structure using a Randomized Complete Block Design with three replicates. The first SMS was the control treatment (T1), which included standard soil management practices in terms of water and nutrient management as recommended by the Department of Agriculture, Sri Lanka. In T1, the total nutrient requirement of the crop was supplied as inorganic fertilizer. Treatments T2 and T3 were soil management systems aimed at arresting the decline of soil fertility and improving the longterm physical fertility of the soil in arable uplands in a future climate. Paddy straw mulch was applied at the rate of $8 \mathrm{tha}^{-1}$ in the second SMS (T2) while other crop management practices were done as in the control treatment. Twenty five percent of inorganic nitrogen was replaced with organic manure (applied in the form of compost) in the third SMS (T3) while other crop management practices were done as in T2. Seeding was done at the spacing of $60 \mathrm{~cm} \times 30 \mathrm{~cm}$ on plots of $5 \mathrm{~m} \times 5 \mathrm{~m}$ keeping one plant per hill to maintain a plant density of 55555 plants ha ${ }^{-1}$.

Soil samples were taken from $0-30 \mathrm{~cm}$ depth before planting and analyzed for bulk density, texture (Smith, 2001), total N (Kjeldhal) P (Olsen, Spectrophotometry) K $\left(\mathrm{NH}_{4} \mathrm{OAc}\right.$ extraction and flame photometry), EC and $\mathrm{pH}$ as described in Ranst et al.(1999). Days to $50 \%$ flowering and days to crop maturity were recorded as phenological parameters. Destructive plant samples were taken at the onset of flowering and partitioned into roots, stems and leaves and dried at $60^{\circ} \mathrm{C}$ for 48 hours to determine the plant biomass. Leaf area was measured using a portable leaf area meter (LI 202, CID, Inc.). Number of cobs per plant, 
number of seeds per cob and hundred seed weight, total grain weight and total biomass were measured at the final harvest. The data recorded as counts were subjected to non parametric analysis (Proc CATMOD) while continuous data were analyzed using the General Linear Model (Proc GLM) procedures at $\mathrm{p}=0.05$ to test the significance of observed differences using the software, Statistical Analysis System, Version 9.0. Since treatments were nested within locations, it was first tested whether location effects and soil management effects were significant within the nested system using "Location (Soil management system)" as an error term. If effects were significant, then tested for significant differences between locations in each soil management system to quantify the performance across the ecological gradient. Finally, it was analyzed whether there was any significant difference between soil management systems in each of the location separately.

The rate of phenological development was calculated by taking the reciprocal of the respective durations from germination to tasseling and germination to maturity. The responses of growth and yield parameters to the temperature gradient were quantified by fitting second-order polynomial curves against the mean location temperature during the season using regression analysis. The respective optimum temperatures were estimated by taking the first derivative of the fitted polynomial equation and equating the independent variable (i.e. mean location temperature) to zero.

\section{RESULTS AND DISCUSSION}

There was a significant $(\mathrm{p}<0.05)$ difference among locations in total soil $\mathrm{N}$ and organic matter contents, $\mathrm{pH}$ and $\mathrm{EC}$ while soil exchangeable $\mathrm{K}$ content did not vary significantly among sites. Mahailluppallama had the highest total soil $\mathrm{N}$ and exchangeable $\mathrm{K}$ and the second highest EC (Table 2). On the other hand, Kilinochchi had the lowest total soil $\mathrm{N}$ and organic matter contents and soil $\mathrm{pH}$ while having the highest EC. Rahangala had the lowest exchangeable $\mathrm{K}$ and $\mathrm{EC}$ while having the second lowest total soil $\mathrm{N}$ and $\mathrm{pH}$. However, the soil organic matter content was highest at Rahangala. Soil pH was around 6-6.7 in all sites while fairly high EC values were recorded in Mahailluppallama and Killinochchi. Higher EC values are characteristic to the soils in the low country Dry zone where salinity levels are high (Kumaragamage \& Kendaragma, 2010).

Table 2. Initial soil nutrient status of experimental sites at $\mathbf{0}-\mathbf{3 0} \mathrm{cm}$ depth

\begin{tabular}{|c|c|c|c|c|c|}
\hline Location & $\begin{array}{l}\text { Total Nitrogen } \\
\qquad\left(\mathrm{mg} \mathrm{g}^{-1}\right)\end{array}$ & $\begin{array}{c}\text { Exchangeable } \\
\text { K (ppm) }\end{array}$ & $\begin{array}{c}\text { Organic } \\
\text { matter }(\%)\end{array}$ & pH & $\begin{array}{c}\mathrm{EC} \\
\left(\mu \mathrm{cm}^{-1}\right)\end{array}$ \\
\hline Rahangala & $0.76^{\mathrm{b}}$ & $172^{\mathrm{a}}$ & $1.67^{\mathrm{a}}$ & $6.2^{b}$ & $105.6^{\mathrm{c}}$ \\
\hline Peradeniya & -* & $182^{\mathrm{a}}$ & - & 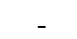 & - \\
\hline Kundasale & $0.84^{\mathrm{ab}}$ & $240^{\mathrm{a}}$ & $1.14^{\mathrm{ab}}$ & $6.4^{b}$ & $177.7^{b c}$ \\
\hline Mahailluppallama & $0.99^{\mathrm{a}}$ & $384^{\mathrm{a}}$ & $0.97^{\mathrm{b}}$ & $6.7^{\mathrm{a}}$ & $328.5^{\mathrm{ab}}$ \\
\hline Killinochchi & $0.68^{\mathrm{b}}$ & $292^{\mathrm{a}}$ & $0.90^{\mathrm{b}}$ & $6.0^{\mathrm{b}}$ & $405.6^{\mathrm{a}}$ \\
\hline $\mathrm{CV}(\%)$ & 9.6 & 33.0 & 22.8 & 2.4 & 29.4 \\
\hline
\end{tabular}

* Not measured; Along each column, means with the same letter are not significantly different at $\mathrm{p}=0.05$.

All locations experienced a fairly well-distributed rainfall pattern during their respective growing seasons (Fig. 1). This is a characteristic feature of the North-East monsoon which brings rain during the maha season. Total rainfalls received during the growing season at Rahangala, Peradeniya, Kundasale, Mahailluppallama and Killinochchi were 630, 704, 723, 482 and $581 \mathrm{~mm}$, respectively. As the seasonal rainfall requirement for maize is around 500- 
$600 \mathrm{~mm}$ (Anon, 1998), rainfall at all locations was sufficient to ensure that the crops did not experience water stress. The lowest daily mean temperature was recorded at Rahangala while Mahailluppallama recorded the highest throughout the cropping period (Fig. 2). A slight increasing trend in the daily mean temperature was observed at Peradeniya Kundasale, Mahailluppallama and Killinochchi from the beginning of the season up to the end. The respective seasonal mean temperatures were 20.7, 25.5, 25.2, 27.6 and $28.8{ }^{\circ} \mathrm{C}$ at Rahangala, Peradeniya, Kundasale, Mahailluppallama and Kilinochchi.
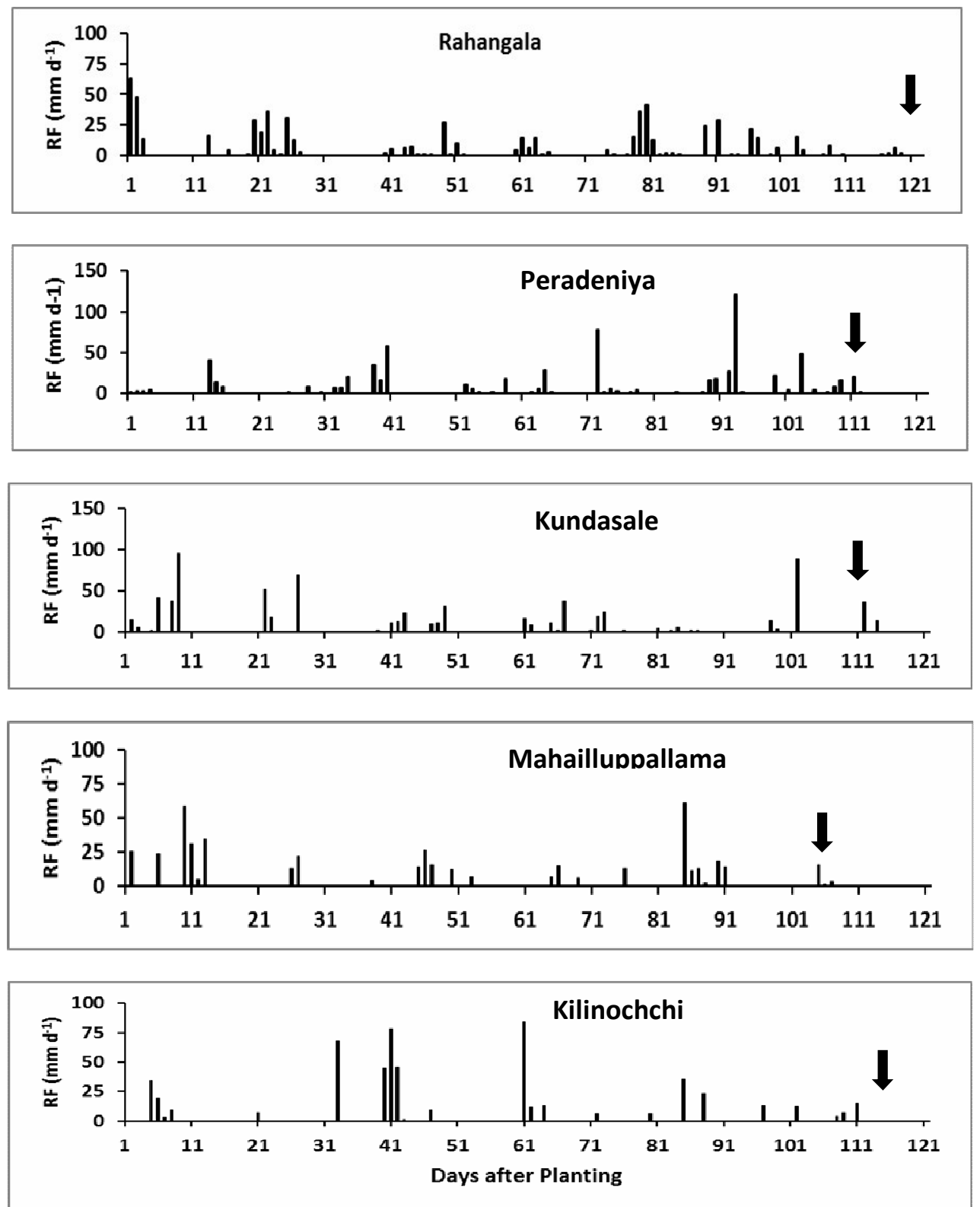
Fig. 1. Rainfall distribution during the cropping season of each location. Data from Vavuniya were used for Kilinochchi. Vertical arrows indicate the respective dates of harvesting at each location.

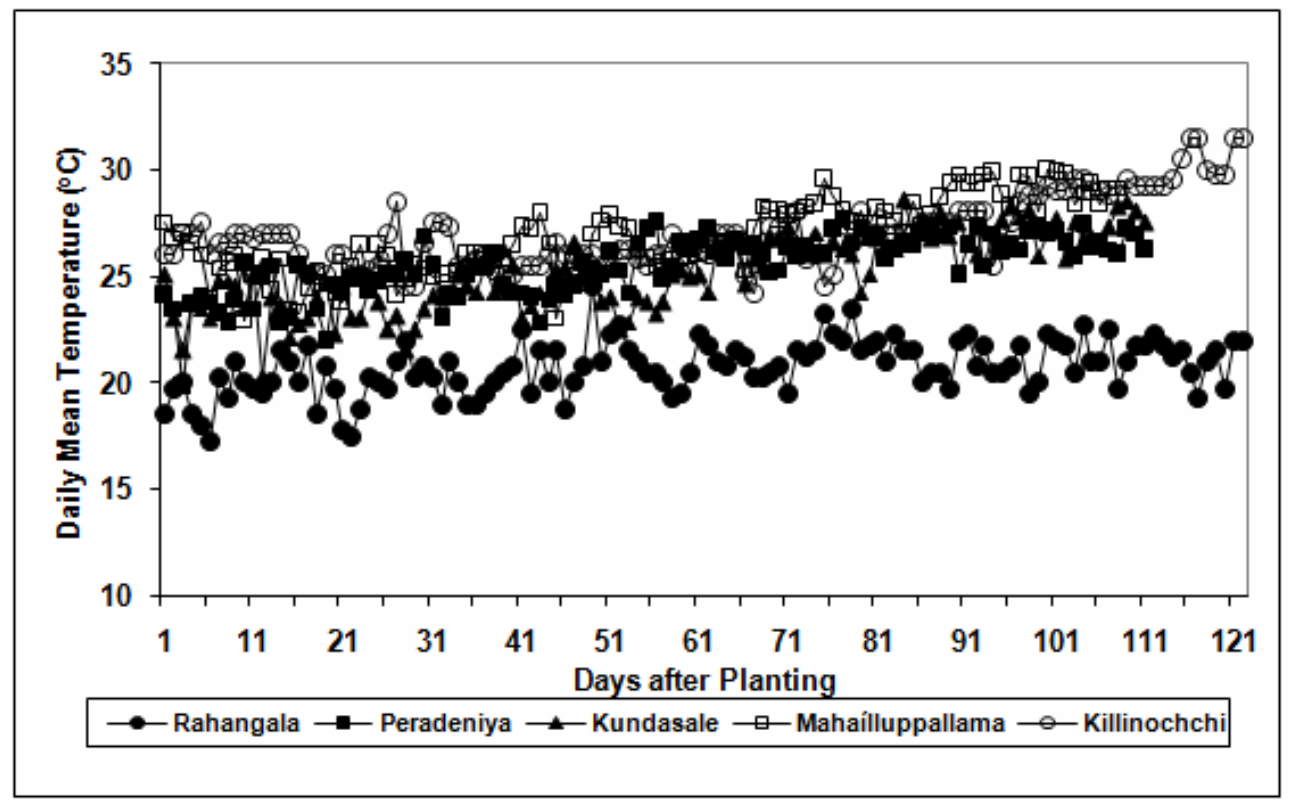

Fig. 2. Seasonal variation of daily mean temperature at each location

\section{Variation of Crop Phenological Development of Maize across the Environmental} Gradient

Soil management systems and their interaction with the location did not show significant variation with respect to days to 50\% flowering and days to final harvest whereas, there was a significant location effect on the above parameters (Table 3). Flowering and crop maturity at Rahangala occurred, 20-23 days and 37-45 days respectively later than at other locations. When calculated with a base temperature of $10{ }^{\circ} \mathrm{C}$, thermal duration for tasseling varied between $790{ }^{\circ} \mathrm{C}-832{ }^{\circ} \mathrm{Cd}$ with an average of $811{ }^{\circ} \mathrm{Cd}$ (Table 3). On the other hand, the corresponding thermal durations for maturity ranged from $1262{ }^{\circ} \mathrm{Cd}$ at Rahangala to 1653 ${ }^{\circ} \mathrm{Cd}$ at Peradeniya with an average of $1551{ }^{\circ} \mathrm{Cd}$. It is a well-established fact that phenological events of maize get extended in cooler environments (Kling and Edmeades, 1997) because a greater time is required to fulfill the required thermal durations. Therefore, even though the total life cycle duration of the variety Ruwan is stated as 110-120 days (Anon, 1990), its duration can be extended in cooler environments (e.g. Rahangala) and shortened in warmer environments (e.g. Mahailluppallama and Kilinochchi). Interestingly, the rate of progress to maturity, defined as the reciprocal of the duration from planting to maturity, showed a highly-significant $(\mathrm{p}<0.0001)$ positive linear relationship with mean location temperature across the five locations (Fig. 3.b). A less strong positive and linear relationship was shown between the rate of progress to tasseling and mean location temperature (Fig. 3.a). 
Table 3. Days to $50 \%$ flowering and final harvest at different locations

\begin{tabular}{lcccc}
\hline System & $\begin{array}{c}\text { Days to 50\% } \\
\text { tasseling }\end{array}$ & $\begin{array}{c}\text { Thermal } \\
\text { duration for } \\
\mathbf{5 0 \%} \text { tasseling } \\
\text { ('C days) }\end{array}$ & $\begin{array}{c}\text { Days to final } \\
\text { harvest }\end{array}$ & $\begin{array}{c}\text { Thermal } \\
\text { duration for } \\
\text { final harvest } \\
\text { ('C days) }\end{array}$ \\
\hline Rahangala & 80 & 793 & 122 & 1263 \\
Peradeniya & 59 & 795 & 111 & 1653 \\
Kundasale & 57 & 790 & 111 & 1643 \\
Mahaillppallama & 59 & 807 & 105 & 1645 \\
Killinochchi & 60 & 832 & 103 & 1553 \\
\hline
\end{tabular}
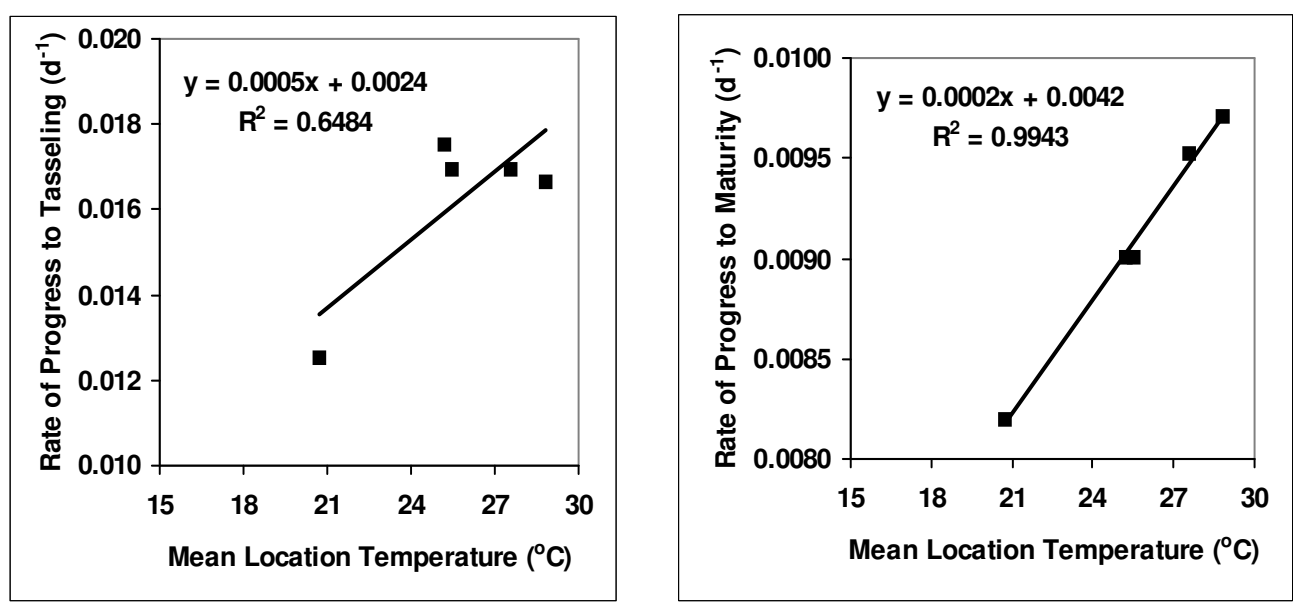

Fig. 3. Relationships between rates of phenological development and mean location temperature: (a) Tasseling; (b) Crop maturity.

\section{Variation of Crop Growth of Maize across the Environmental Gradient}

The two principal crop growth variables, leaf area index (LAI) and total dry weight (TDW) at 50\% flowering of maize crops in all soil management systems (SMS) showed significant second-order polynomial relationships with mean location temperature across the five locations representing the environmental gradient (Figs. 4 and 5). The respective optimum temperatures for maximum LAI were within a very narrow range for all SMS (Table 5), with the mean optimum being $23.0{ }^{\circ} \mathrm{C}$. The estimated maximum LAI of the T2 treatment (i.e. mulched, but $100 \%$ of $\mathrm{N}$ requirement from inorganic fertilizer) was $6 \%$ greater than $\mathrm{T} 1$ and T3. This was probably because of the greater soil moisture conservation and the readily available $\mathrm{N}$ for leaf growth in T2 as compared to T1 (No mulch) and T3 (Only 75\% of $\mathrm{N}$ requirement from inorganic fertilizer). The optimum temperatures for maximum TDW also fell within a narrow range (i.e. $22.4-22.9{ }^{\circ} \mathrm{C}$ ) with the mean optimum being $22.8{ }^{\circ} \mathrm{C}$. However, the estimated maximum TDW was $22 \%$ greater in T3 (mulching $+75 \%$ of $\mathrm{N}$ supplied by inorganic fertilizer $+25 \% \mathrm{~N}$ from organic manure) in comparison to T1. TDW of $\mathrm{T} 2$ also was $9 \%$ greater than that of T1. These higher TDWs of T2 and T3 reflected the beneficial effects of mulching (Holland, 2004; Brevault, et al., 2007) and organic manure over the course of the season. 


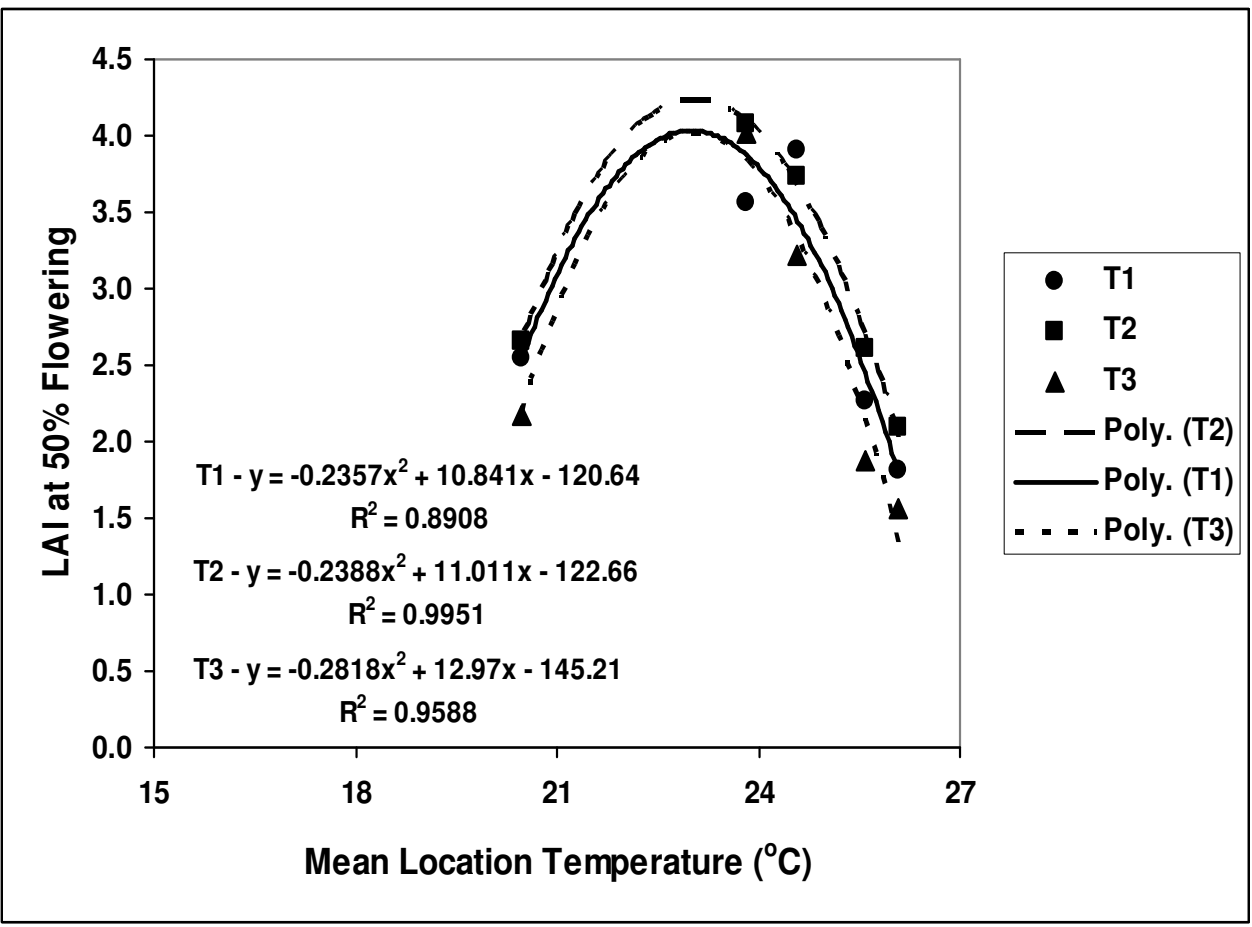

Fig. 4. Relationships between mean location temperature up to $50 \%$ flowering and leaf area index (LAI) at $50 \%$ flowering in different soil management systems: T1-Recommended soil management (Control); T2-Mulching at $8 \mathrm{t}$ $\mathrm{ha}^{-1}$; T3-Mulching at $8 \mathrm{t} \mathrm{ha}^{-1}$ plus $25 \%$ of $\mathrm{N}$ requirement supplied through organic manure (See text for further details on experimental treatments).

Table 5. Estimated optimum temperatures for maximum leaf area index (LAI) and total crop dry weight (TDW) of maize at $50 \%$ flowering in different soil management systems

\begin{tabular}{ccccc}
\hline & \multicolumn{2}{c}{ LAI } & \multicolumn{2}{c}{ TDW } \\
\cline { 2 - 5 } & $\begin{array}{c}\text { Optimum } \\
\text { Temperature }\left({ }^{\mathbf{0}} \mathbf{C}\right)\end{array}$ & Maximum LAI & $\begin{array}{c}\text { Optimum } \\
\text { Temperature }\left({ }^{\mathbf{0}} \mathbf{C}\right)\end{array}$ & $\begin{array}{c}\text { Maximum TDW } \\
\left(\mathbf{g ~ m ~}^{-\mathbf{2}}\right)\end{array}$ \\
\hline $\mathrm{T} 1$ & 23.00 & 4.02 & 22.84 & 668 \\
$\mathrm{~T} 2$ & 23.05 & 4.27 & 22.37 & 727 \\
$\mathrm{~T} 3$ & 23.01 & 4.03 & 22.98 & 817 \\
\hline Pooled* & 23.02 & 4.09 & 22.83 & 737 \\
\hline * Based on the polynomial curve fitted to the pooled data from all three treatments.
\end{tabular}




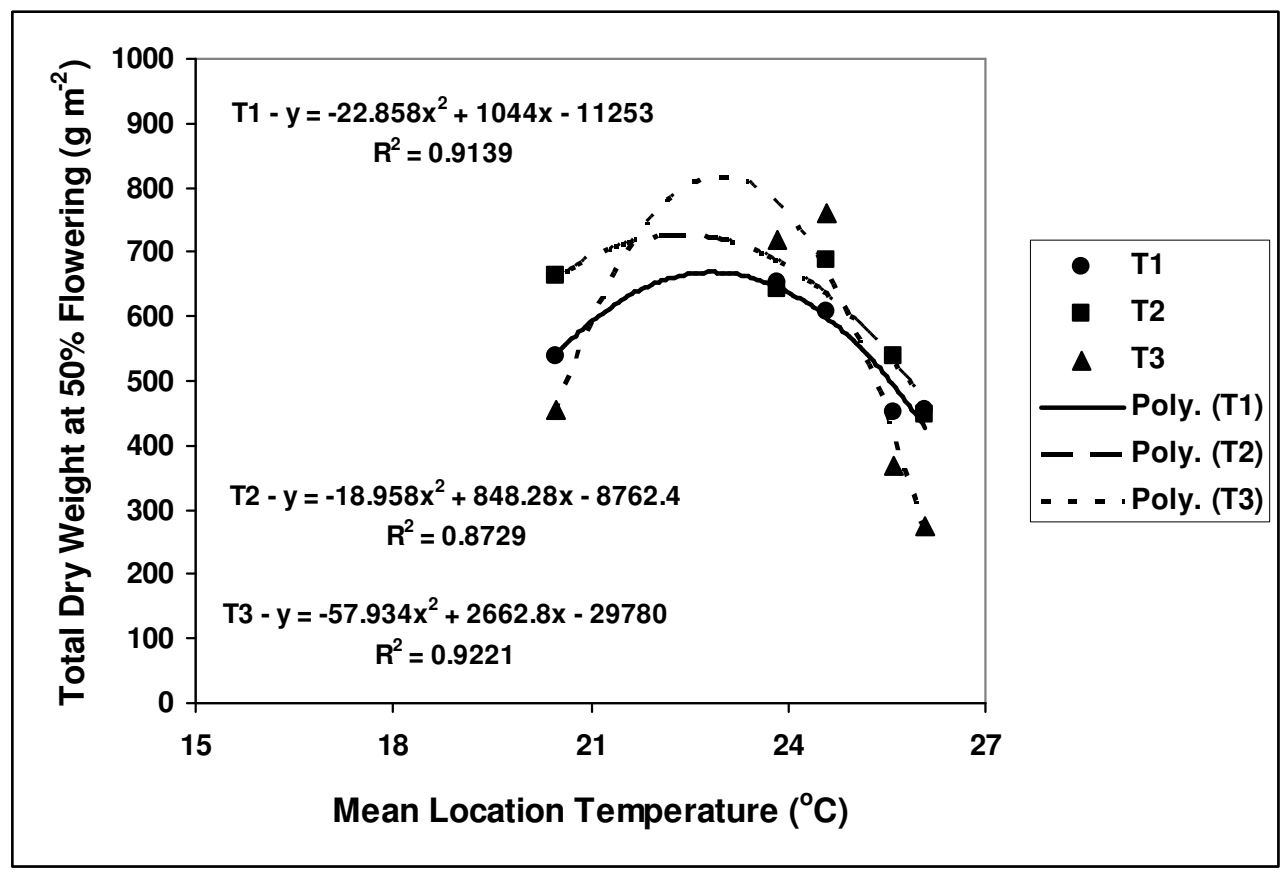

Fig. 5. Relationships between mean location temperature up to $50 \%$ flowering and total crop dry weight (TDW) of maize at $50 \%$ flowering in different soil management systems.

The respective optimum temperatures at which LAI and TDW (Table 5) fell between the mean location temperature at Rahangala and those of the rest of the locations (Table 1 and Fig. 2). This indicated that crop growth of maize was restricted by the lower temperatures at Rahangala. Although growth was stimulated at the higher temperatures at the rest of the locations, all other locations were in the supra-optimal range. Therefore, the maximum crop growth was observed at Peradeniya and Kundasale, which had intermediate temperatures. Significant reductions in growth were observed with increasing temperatures at MI and Kilinochchi. Linear regressions fitted to the sub-optimal and supra-optimal temperature ranges of the pooled polynomial curves for LAI and TDW enabled quantification of the sensitivity of maize growth increasing temperature. In the sub-optimal temperature range, for each $1^{\circ} \mathrm{C}$ increase in mean growing season temperature, LAI and TDW at 50\% flowering increased by 0.33 and $33 \mathrm{~g} \mathrm{~m}^{-2}$, respectively. On the other hand, in the supra-optimal range, LAI and TDW at 50\% flowering decreased by 0.98 and $139 \mathrm{~g} \mathrm{~m}^{-2}$, respectively with each $1^{\circ} \mathrm{C}$ increase in mean seasonal temperature. Therefore, across the environmental gradient used in the present study, the magnitude of negative impacts on vegetative growth of maize in the supra-optimal temperature range is greater than the magnitude of positive impacts in the sub-optimal range. This is in agreement with White \& Reynolds (2003) who reported that the temperature has a dominant effect on crop development resulting in lower LAI and canopy growth simply because of the shorter growth duration at higher temperatures. It is worth noting that temperatures of the major maize growing regions in Sri Lanka (i.e. the dry and intermediate zones) fall within the supra-optimal range. Therefore, despite being a $\mathrm{C} 4$ crop, the growth of maize would be negatively affected by the expected future increases of temperature in the dry and intermediate zones of Sri Lanka. 


\section{Variation of Grain Yield of Maize across the Environmental Gradient}

Grain yield of maize crops in T1 and T3 showed significant second-order polynomial relationships with mean location temperature across the five locations representing the environmental gradient (Fig. 6). On the other hand, T2 showed a negative linear relationship. When the data for all three SMSs were pooled, an overall second-order polynomial relationship was shown (Fig. 7). The estimated optimum temperature for grain yield (i.e. $22.5^{\circ} \mathrm{C}$ ) (Table 6) was very close to the respective optima for growth of maize up to $50 \%$ flowering (Table 5) and it falls within the range of optimum temperature for growth and development of maize (Belfield and Brown, 2008). In contrast to the response of growth parameters, the increase of maize yield in response to increasing temperature in the suboptimal range was only marginal with $15 \mathrm{~kg} \mathrm{ha}^{-1}{ }^{\circ} \mathrm{C}^{-1}$. On the other hand, maize yield was highly sensitive to increasing temperature in the supra-optimal range with a reduction of 489 $\mathrm{kg} \mathrm{ha}^{-1}$ for each $1^{\circ} \mathrm{C}$ increase in mean growing season temperature. As all the major maize growing regions are located in the supra-optimal range in terms of its yield response to temperature, future climate change will have significant negative impacts on maize yields in Sri Lanka, unless more heat-tolerant varieties are bred and introduced.

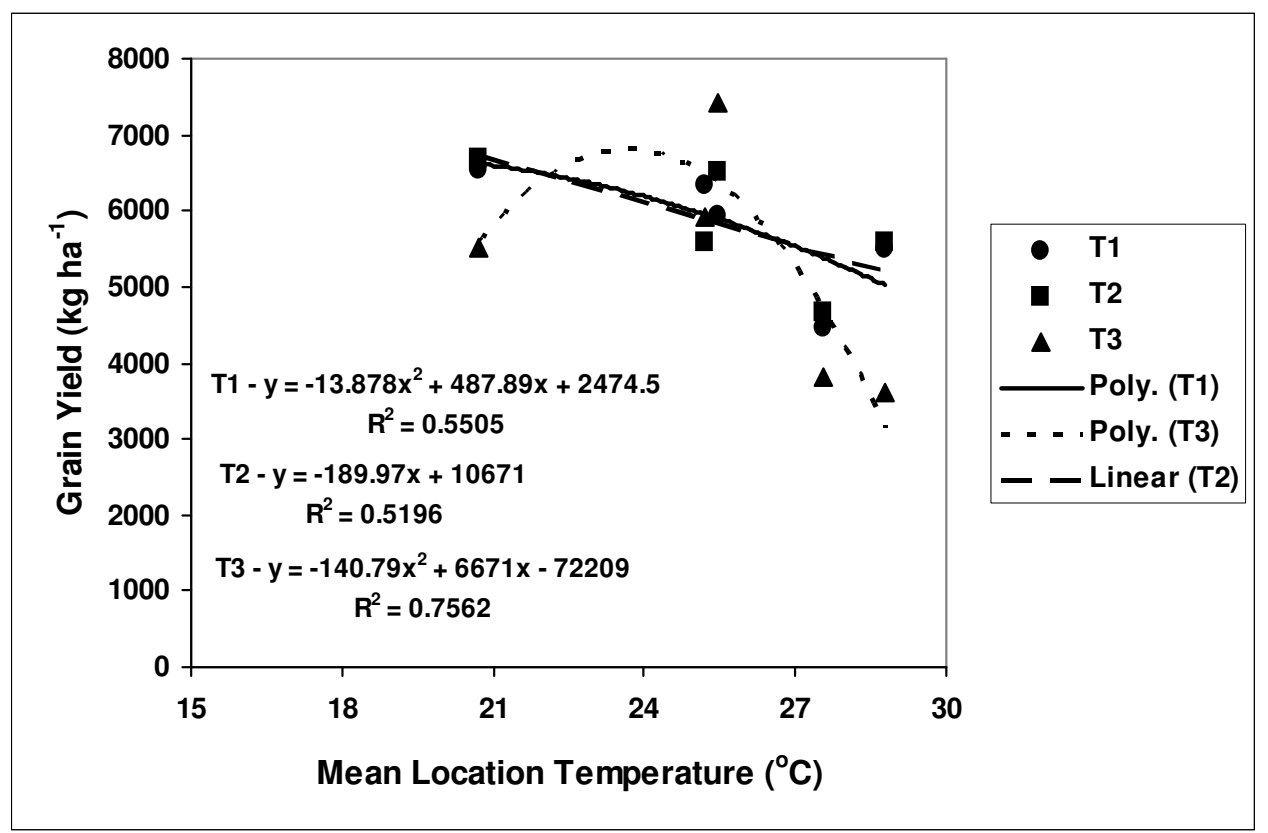

Fig. 6. Relationships between mean location temperature throughout the season and grain yield of maize in different soil management systems.

Table 6. Estimated optimum temperatures and maximum grain yields of maize in different soil management systems.

\begin{tabular}{lcc}
\hline & Optimum Temperature $\left({ }^{\mathbf{0}} \mathbf{C}\right)$ & Maximum Yield $\left(\mathbf{k g ~ h a}^{-1}\right)$ \\
\hline T1 & 17.6 & 6763 \\
T2 & - & $6735^{*}$ \\
T3 & 23.7 & 6813 \\
\hline Pooled & 22.5 & 6478 \\
\hline
\end{tabular}

\footnotetext{
* Estimate grain yirld at the mean location temperature at Rahangala based on the fitted linear relationship.
} 


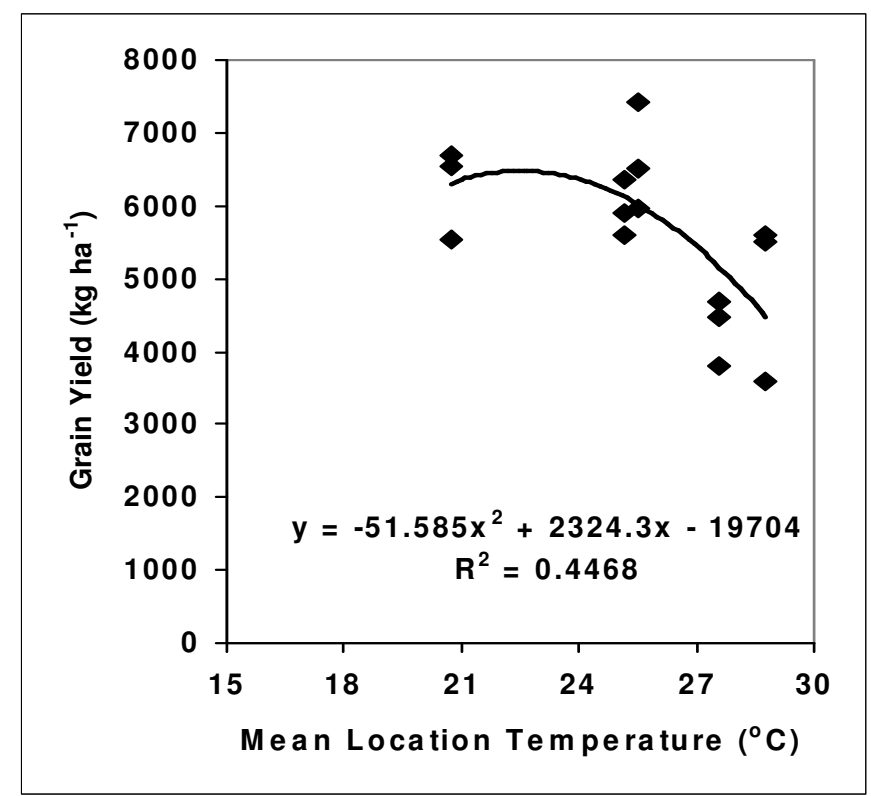

Fig. 7. Relationship between mean location temperature and grain yield of maize when data from all soil management systems were pooled

Relationships between grain yield and vegetative growth of maize across the environmental gradient

Highly-significant second-order polynomial relationships were observed between grain yield and LAI $(\mathrm{p}=0.0047)$ and TDW $(\mathrm{p}<0.0001)$ at $50 \%$ flowering (Fig. 8). Furthermore, TDW at $50 \%$ flowering showed a highly-significant $(\mathrm{p}<0.0001)$ positive relationship with grain yield (Fig. 9). The respective optimum LAI at 50\% flowering to achieve maximum TDW at $50 \%$ flowering and maximum grain yield were 3.61 and 3.25 respectively. Fitted polynomial relationships between LAI at 50\% flowering and mean seasonal temperature (Fig. 4) show that the above optimum LAIs are achieved when the mean temperature at the vegetative stage is around $21-22^{\circ} \mathrm{C}$. 


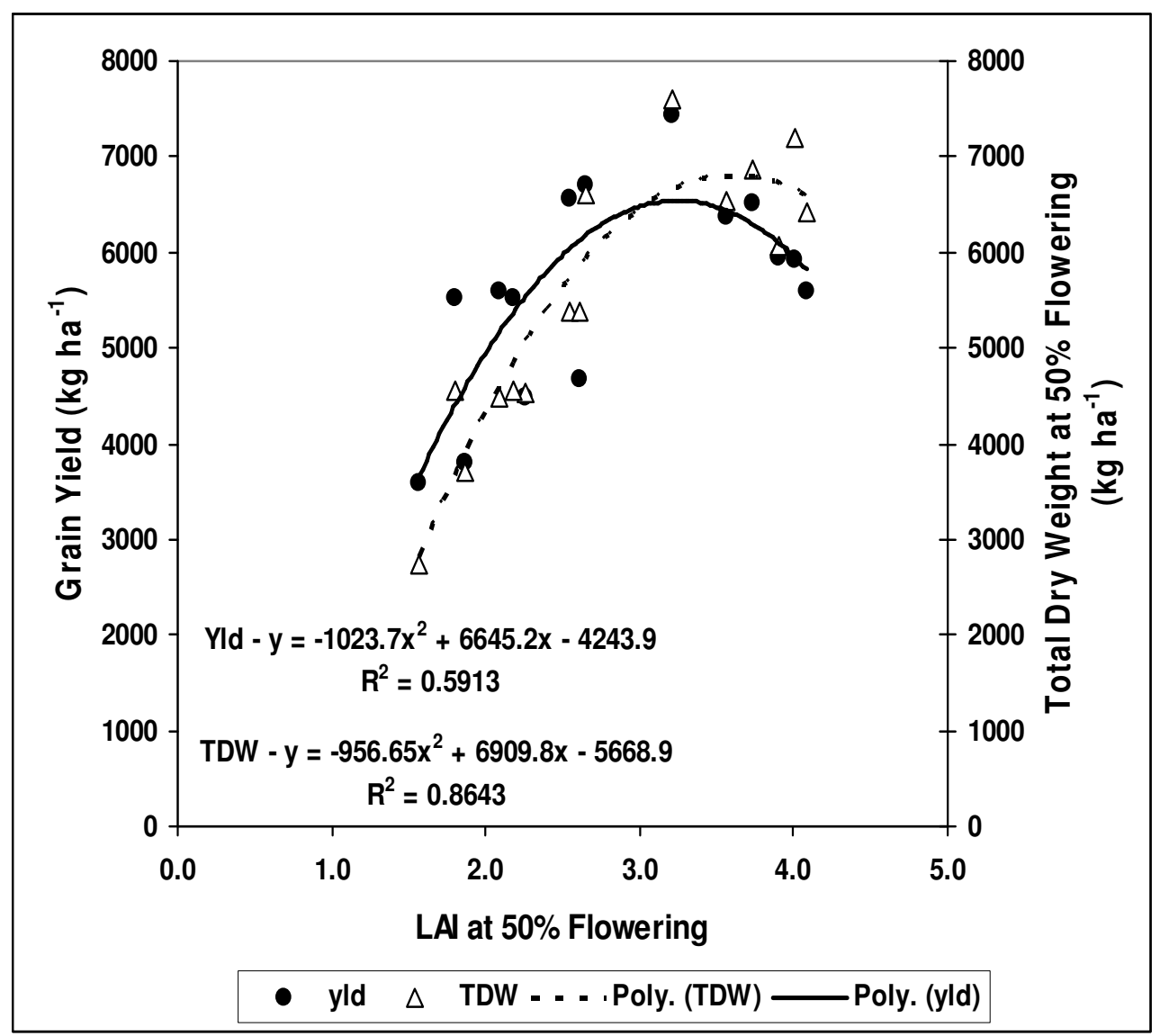

Fig. 8. Relationships between leaf area index (LAI) at $50 \%$ flowering and grain yield and total dry weight at $50 \%$ flowering of maize across the environmental gradient and soil management systems. 


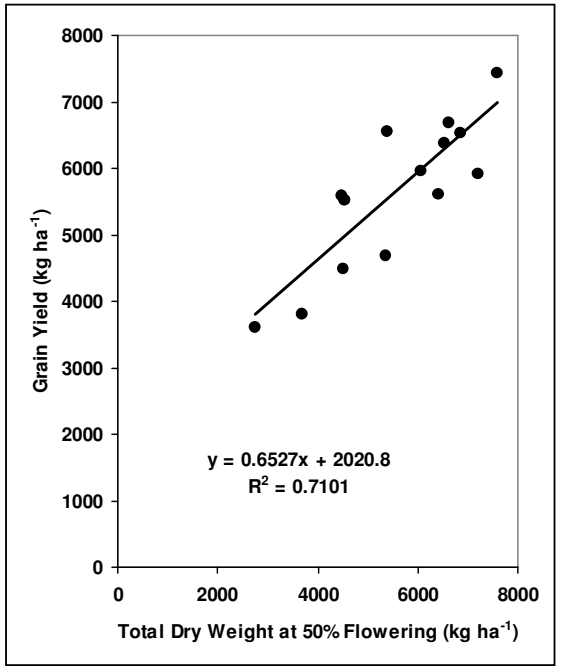

Fig. 9. Relationship between total dry weight at $50 \%$ flowering and grain yield of maize across the environmental gradient and soil management systems.

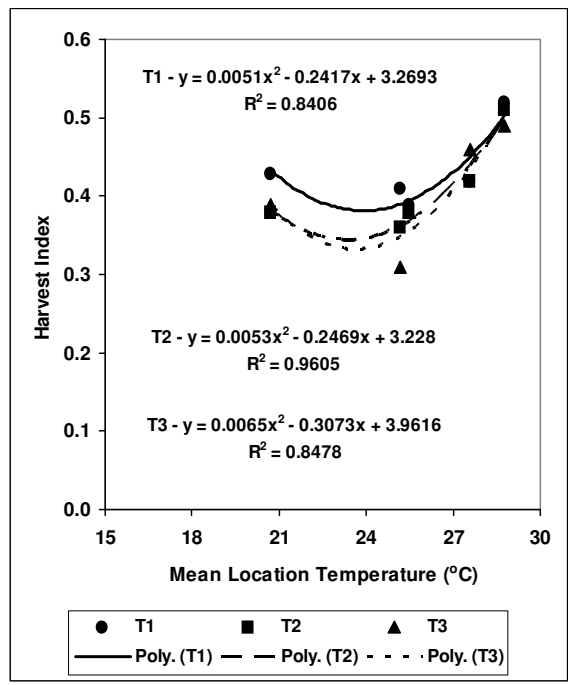

Fig. 10. Relationship between mean location temperature and harvest index of maize in different soil management systems.

Relationships between grain yield, harvest index and total dry weight at harvest of maize

Grain yield showed a highly-significant $(\mathrm{p}=0.0005)$ correlation between TDW at harvest $(\mathrm{r}=$ $0.787)$, which in turn showed a highly-significant $(\mathrm{p}=0.0023)$ correlation with TDW at $50 \%$ flowering $(r=0.723)$. In contrast, grain yield showed a negative correlation $(r=-0.473$, $\mathrm{p}=0.075)$ with harvest index $(\mathrm{HI})$, which in turn showed a highly-significant $(\mathrm{p}=0.0007)$ negative correlation $(\mathrm{r}=-0.775)$ with TDW at 50\% flowering. However, HI did not show a significant $(\mathrm{p}=0.05)$ correlation with TDW at harvest. Interestingly, HI showed a significant $(\mathrm{p}<0.0001)$ second-order polynomial relationship with mean location temperature across the environmental gradient (Fig. 10), which was in the opposite direction to the corresponding relationships of grain yield, LAI and TDW at 50\% flowering (Figs. 7, 4 and 5), with the respective optimum temperatures ranging from 23.3 to $23.7{ }^{\circ} \mathrm{C}$ for the different SMSs. This meant that $\mathrm{HI}$ decreased with increasing temperature in the sub-optimal range and increased with increasing temperature in the supra-optimal range. As HI is the ratio between grain yield and TDW at harvest, the direction of change in HI would be determined by the relative magnitudes of change in grain yield and TDW. As grain yield increased at a slower rate than TDW during the sub-optimal range (Figs. 7 and 5), HI decreased within the sub-optimal range of temperatures. On the other hand, grain yield decreased at a slower rate than TDW during the supra-optimal range and consequently increased the HI. Lafitte and Edmeades (1997) observed that HI of highland maize cultivars decreased from values of 0.35 to almost zero when the mean growing temperatures increased from $17^{\circ} \mathrm{C}$ to $28^{\circ} \mathrm{C}$.

\section{Relationships between grain yield and yield components}

Out of the three yield components, only the number of seeds per cob showed a significant $(\mathrm{p}<0.0001)$ positive correlation $(\mathrm{r}=0.872)$ with grain yield. In contrast, the number of cobs 
per plant and the 100-seed weight did not show significant correlations to grain yield. There were no significant correlations between seed number per cob and the other two yield components, indicating that the seed number per cob is determined independently from other yield components. However, the seed number per cob, which is a measurement of the sink size, showed highly significant positive correlations with LAI $(r=0.732, p=0.0019)$ and TDW at 50\% flowering $(\mathrm{r}=0.912, \mathrm{p}<0.0001)$ and TDW at harvest $(\mathrm{r}=0.785, \mathrm{p}=0.0005)$. The significant correlation with LAI indicates that sink size of maize is determined by the source capacity.

\section{Analysis of variance of growth and yield parameters}

The location effect and the interaction effect between location and soil management systems were significant for all the measured growth and yield parameters (Table 7). The tested SMSs did not have significant effects on LAI and TDW at 50\% flowering at Rahangala, Peradeniya, Kundasala and Mahailluppallama whereas significant reductions were observed at Killinochchi for both parameters in $\mathrm{T} 3$, where $25 \%$ of the $\mathrm{N}$ requirement was given as organic manure (Figs. 4 and 5). Similarly, at Kilinochchi, T3 showed a significant yield reduction in comparison to the other SMSs (Fig. 6). The lower soil N status in Kilinochchi may have been responsible for the observed growth and yield reductions in T3. It is notable that at all locations except Kilinochchi, it was possible to replace $25 \%$ of the $\mathrm{N}$ requirement of maize with organic manure without suffering significant growth or yield reductions. On the other hand, the short time period of one season might not be adequate for the mulching treatment in T2 or the organic matter treatment in T3 to cause significant positive impacts on growth and yield. The present experiment will be continued over three more seasons and these expected positive effects of T2 and T3 treatments may be observed in the coming seasons. The TDW at harvest also showed a significant reduction in T3 in comparison to T1 and $\mathrm{T} 2$ at Kilinochchi, but not at other locations. In contrast, HI did not show significant variation between SMSs at all locations.

Table 7. Location and treatment effects in the nested treatment structure of measured growth and yield parameters

\begin{tabular}{lcc}
\hline \multicolumn{1}{c}{ Parameter } & Type III probability* & CV (\%) \\
\hline Leaf area & 0.0001 & 20.1 \\
Total biomass & 0.0001 & 24.2 \\
Total grain yield & 0.0132 & 17.2 \\
Number of seeds per cob & 0.0460 & 19.3 \\
Hundred seed weight & 0.0003 & 11.4 \\
\hline
\end{tabular}

*When testing the hypothesis using the type III mean square for "Location (Soil management system) as an error term.

The number of seeds per cob and 100-seed weight also showed a similar pattern of variation to the growth and yield parameters with significant differences between SMSs being shown only at Kilinochchi (Table 8). Here also, T3 showed significant reductions of these two yield components as compared to T1 and T2, which did not differ significantly. However, the number of cobs per plant did not vary significantly among different SMSs (data not shown). 
Table 8. Variation of the number of seeds per cob and 100-seed weight of maize at different locations in different soil management systems

\begin{tabular}{|c|c|c|c|c|c|c|c|c|c|c|}
\hline & Rahangala & & Peradeniya & & Kundasala & & Mahailluppall & & Killinochchi & \\
\hline System & $\begin{array}{l}\text { Seed number } \\
\operatorname{cob}^{-1}\end{array}$ & $\begin{array}{l}\text { 100-seed } \\
\text { weight } \\
(\mathrm{g}) \\
\end{array}$ & $\begin{array}{l}\text { Seed number } \\
\operatorname{cob}^{-1}\end{array}$ & $\begin{array}{l}\text { 100-seed } \\
\text { weight }(\mathrm{g})\end{array}$ & $\begin{array}{l}\text { Seed } \\
\text { number cob- } \\
1\end{array}$ & $\begin{array}{l}\text { 100- seed } \\
\text { weight }(\mathrm{g})\end{array}$ & $\begin{array}{l}\text { Seed number } \\
\text { cob }^{-1}\end{array}$ & $\begin{array}{l}\text { 100-seed } \\
\text { weight }(g)\end{array}$ & $\begin{array}{l}\text { Seed number } \\
\text { cob }^{-1}\end{array}$ & $\begin{array}{l}100 \text {-seed } \\
\text { weight }(\mathrm{g})\end{array}$ \\
\hline $\mathrm{T} 1$ & $445 \mathrm{a}$ & $26.8 \mathrm{a}$ & $439 a$ & $22.4 \mathrm{a}$ & $471 \mathrm{a}$ & $21.0 \mathrm{a}$ & $360 \mathrm{a}$ & $25.3 \mathrm{a}$ & 399 a & $32.1 \mathrm{a}$ \\
\hline $\mathrm{T} 2$ & $441 \mathrm{a}$ & $27.6 \mathrm{a}$ & $444 \mathrm{a}$ & $27.2 \mathrm{a}$ & $483 \mathrm{a}$ & $20.3 \mathrm{a}$ & $411 \mathrm{a}$ & $22.6 \mathrm{a}$ & $414 \mathrm{a}$ & $31.3 \mathrm{a}$ \\
\hline $\mathrm{T} 3$ & $367 \mathrm{a}$ & $27.8 \mathrm{a}$ & $553 \mathrm{a}$ & $23.0 \mathrm{a}$ & $451 \mathrm{a}$ & $18.3 \mathrm{a}$ & $347 \mathrm{a}$ & $21.9 \mathrm{a}$ & $293 \mathrm{~b}$ & $28.2 \mathrm{~b}$ \\
\hline $\mathrm{CV}(\%)$ & 14.3 & 4.9 & 31.1 & 16.4 & 20.6 & 15.9 & 10.5 & 13.2 & 6.4 & 10.1 \\
\hline
\end{tabular}




\section{CONCLUSIONS}

The present experiment was conducted in the maha season in which rainfall and soil water availability was adequate for the maize crops to grow without any limitation of water. Therefore, the observed responses of maize crops in the present study could be considered as the crops' response to the temperature gradient across the environmental gradient as represented by this multi-locational experiment. The present study was able to establish clear and statistically-significant response patterns and identify the optimum temperatures for growth and yield of the Sri Lankan in-bred maize variety Ruwan under the environmental and management conditions found in Sri Lanka. It can also be noted that the above results were obtained in spite of the soil variation that is present across the environmental gradient thus showing that climatic effects dominate over soil effects at least during the maha season in which soil water is not a limiting factor. All the major maize growing regions are located in the supra-optimal range in terms of its yield response to temperature and therefore future climate change will have significant negative impacts on maize yields in Sri Lanka. In addition, the different soil managements systems tested at all locations except in the location with the highest temperature (i.e. Kilinochchi), indicated the possibility of replacing $25 \%$ of the $\mathrm{N}$ requirement of maize with organic manure without suffering significant growth or yield reductions. However, a single season might not be adequate for the mulching (T2) and organic manure treatments (T3) to make significant positive impacts on growth and yield and therefore, the experiment will be continued over three more seasons to see positive effects of mulching and organic manure treatments.

\section{ACKNOWLEDGMENT}

The authors wish to acknowledge the financial support given by the HETC- QIG- Window 3 project to carry out the experiments.

\section{REFERENCES}

Anonymous. (1990). Crop Recommendations Technoguide, Department of Agriculture, Sri Lanka, pp. 1-3.

Anonymous. (1998). Saubhagyamath Sri Lankawak Sandaha. Crop recommendations. (In Sinhala medium) Department of Agriculture, Sri Lanka, pp. 7-9.

Anonymous. (2012). AgStat. The pocket book of agriculture statistics. Socio Economic and Planning Centre, Department of Agriculture, Peradeniya, Sri Lanka, 21p.

Belfield, S. and Brown, C. (2008). Field Crop Manual: Maize. A Guide to Upland Production in Cambodia. NSW Department of Primary Industries. The State of New South Wales, 3p.

Brevault, T., Bikay, S., Maldes, J.M. and Naudin, K. (2007). Impact of a no-till with mulch soil management strategy on soil macro fauna communities in a cotton cropping system. Soil Till. Res. 97, 140-149.

Cline W.R. (1992). The Economics of Global Warming. Peterson Institute for International Economics, 1992. Washington, DC. 
Cook, E. K. (1931). Ceylon, Its Geography, Its Resource and Its People, Macmillan, London

Dassanayake, A.R. and De Silva, G.G.R. (2005). Soils of the up country intermediate zone. pp. 149-164. In: Mapa, R.B., Dassanayake, A.R. and Nayakekorale, H.B. (Eds.). Soils of the Intermediate Zone of Sri Lanka. Morphology, Characterization and Classification. Special Publication No. 4. Soil Science Society of Sri Lanka.

De Costa, W.A.J.M. (2008). Climate change in Sri Lanka: myth or reality? - Evidence from long-term meteorological data. J. Natn. Sci. Foundation Sri Lanka. 36 (Special Issue), 83109.

De Costa, W.A.J.M. (2009). Impacts of climate change on the long-term variation in the water balance of different rainfall seasons in selected locations of Sri Lanka. pp. 51-52. In: Proceedings of the First National Conference on Global Climate Change and its Impacts on Agriculture, Forestry and Water in the Tropics, 10 - 11 September 2009, Kandy, Sri Lanka.

De Silva, G.G.R. and Dassanayaka, A.R. (2010). Dry zone soils derived from erosional surfaces. pp. 86-90. In: Mapa, R.B., Somasiri, S. and Dassanayake, A.R. (Eds.) Soils of the Dry Zone of Sri Lanka. Morphology, Characterization and Classification. Special Publication No. 7. Soil Science Society of Sri Lanka.

De Silva, G.G.R., Dassanayake, A.R. and Mapa, R.B. (2005). Soils of the mid country intermediate zone. pp. 121-125. In: Mapa, R. B., Dassanayake, A. R. and Nayakekorale, H. B. (Eds.). Soil of the Intermediate Zone of Sri Lanka. Morphology, Characterization and Classification. Special Publication No. 4. Soil Science Society of Sri Lanka.

Farmer, B. H. (1956). "Rainfall and water supply in the dry zone of Ceylon", pp 225-268. In: Steel, R.W. and Fisher, C.A. (Eds.), Geographical Essays on British Tropical Lands, George Philip \& Sons Ltd., London.

Fernando, T.K. and Chandrapala, L. (1995). Climate variability in Sri Lanka - A study on trends of air temperature, rainfall and thunder activity. Proceedings of International Symposium on Climate and Life in Asia - Pacific, April 10-13, 1995, Brunai.

Holland, J.M. (2004). The environmental consequences of adopting conservation tillage in Europe: Reviewing evidence. Agric. Ecosyst. Environ. 103, 1-25.

Kendaragama, K.M.A. (1999). Response of tomato and chilli to application of four organic materials on an Alfisol. Annals of the Sri Lanka Department of Agriculture. 1, 108-113.

Kling, J.G. and Edmeade, D. (1997). Morphology and growth of maize. IITA/CIMMYT Research Guide 9 ( $2^{\text {nd }}$ edition). Training Program, International Institute of Tropical Agriculture (IITA), Ibadan, Nigeria, 11p.

Kumaragamage, D. and Kendaragama, K.M.A. (2010). Risks and limitations of dry zone soils. pp. 239-258. In: Mapa R., Somasiri, B. and. Dassanayaka, A.R. (Eds.). Soils of the Dry Zone of Sri Lanka. Morphology, Characterization and Classification. Special Publication No. 7. Soil Science Society of Sri Lanka.

Lafitte, H.R. and Edmeades, G.O. (1997). Temperature effects on radiation use and biomass partitioning in diverse tropical maize cultivars. Field Crops Res. 49, 231-247. 
Madduma Bandara, C. M. (1971). "The Morphometry of Dissection the Central Highlands of Ceylon”, Unpublished Ph. D. Dissertation, St. John`s College, Cambridge University, Cambridge.

Miyashita, Y. (1997): "Effects of Environmental Change on the Water Balance in Sri Lanka", unpublished Ph.D. Dissertation, Department of Geo-sciences, The University of Tsukuba, Japan.

Nijamudeen, M.S., W.D. Lesly and D.M. Jinadasa, (2004). Incorporation of cultivated Other Field Crops as in-situ green manure on the productivity of the Reddish Brown Earth soils of the dry zone of Sri Lanka. J. of Soil Sci. Soc. of Sri Lanka, 15, 38-43.

Panabokke, C.R., and B.V.R. Punyawardena. 2009. Climate change and rainfed agriculture in the dry zone of Sri Lanka. pp. 141-146. In: Evans, A. and Jinapala, K. (Eds.). Proceedings of National Conference on Water Food Security and Climate Change in Sri Lanka. Water quality environment climate change, 2. June 9-11, 2009, BMICH, Colombo..

Pielke, R.A., Prins, G., Rayner, S. and Sarewitz, D. (2007). Lifting the taboo on adaptation. Nature. 445, 597-598.

Punyawardana, B.V.R. (2008). Evolution of climatic zones in Sri Lanka. pp. 44-113. In: Agro-climatological Zones and Rainfall Pattern in Sri Lanka (in Sinhala medium). Published by Department of Agriculture, Sri Lanka.

Rahmsdorf, S., Cazenave, A., Church, J.A., Hansen, J.E., Keeling, R.F., Parker, D.E. and Somerville, R.C.J. (2007). Recent climate observations compared to predictions. Science. $316,709$.

Ranst, V.E., Verloo, M., Demeyer, A. and Pauwels, J.M. (1999). Manual for the soil chemistry and fertility laboratory, analytical methods for soils and plants; Equipments and management of consumables. ISBN 90-76603-01-4. International training center for post graduate soil scientists, Krijgalaan, 281/58, B-9000, Gent, Belgium.

Rekha, K.W.G.N. (2003). "Recent trends of climate change in Sri Lanka", The J. of GeoEnvironment. 3, 37-49.

Rosenzweig, C., Karoly, D., Vicarelli, M., Neofotis, P., Wu, Q., Casassa, G., Menzel, A., Root, T.L., Estrella, N. and Seguin, B. (2008). Attributing physical and biological impacts to anthropogenic climate change. Nature. 453, 353-358.

Senarath, A. and Dissanayake, A.R. (1999). Soils of the mid country wet zone. pp. 97-98. In: Mapa, R.B., Somasiri, S. and Nagarajah, S. (Eds.). Soils of the Wet Zone of Sri Lanka. Morphology, Characterization and Classification. Special Publication No. 1. Soil Science Society of Sri Lanka.

White, J.W. and Reynolds, M.P. (2001). A Physiological perspective on modeling temperature response in wheat and maize crops. pp. 8-17. In: Proceedings of a Workshop, CIMMYT, El Batán, Mexico, 23-25 April 2001. NRG-GIS Series 03-01. México, D.F.: CIMMYT. 